INTERNATIONAL JOURNAL OF RESEARCHES IN BIOSCIENCES, AGRICULTURE AND TECHNOLOGY (C) VISHWASHANTI MULTIPURPOSE SOCIETY (Global Peace Multipurpose Society) R. No. MH-659/13(N) www.vmsindia.org

\title{
NEW SPECIES OF GENUS PHYLLOMYA (DIPTERA: TACHINIDAE) FROM WESTERN MAHARASHTRA, INDIA
}

\author{
P. M. Bhoje ${ }^{1}$, A. S. Desai ${ }^{2}$ and T. V. Sathe ${ }^{2}$ \\ ${ }^{1}$ Department of Zoology, Y. C. Warana Mahavidyalaya, Warananagar, Kolhapur \\ 2Department of Zoology, Shivaji University, Kolhapur
}

\begin{abstract}
:
A new species Phyllomya panhalensis is reported and described for the first time from India. Gena and parafacials appearing silvery but not reddish brown. Antenna silvery-light brown and antennal third segment more than thrice as long as second segment. Vibrissae weak not differentiated from hairs on vibrissal angle. Bend of M distinct and shows small projection of $\mathrm{M}_{2}$ on wing. Abdomen black with white bands, not seen uniformly to naked eye elongated. Legs brownish black with yellow tibia.

Keywords: Phyllomya panhalensis, new species, description, India.
\end{abstract}

\section{Introduction:}

Tachinid flies (Diptera: Tachinidae) are excellent biocontrol agents of many insect pests. The family Tachinidae is one of the largest families of Diptera with 10,000 described species worldwide (Irwin, et al., 2003; Stireman, et al., 2006). Tachinids are parasitic on members of order Hymenoptera, Lepidoptera, Heteroptera, Coleoptera, Orthoptera, and several others (Tschorsnig and Herting, 1994).The family Tachinidae is much larger and widely attempted from Neotropical, Afrotropical and Australasian regions but very little attention is paid on oriental region including India (O'Hara, 2005). Review of literature indicates that, Indian tachinids have been studied by Crosskey (1976), Lahiri (2003; 2006), Sathe et al. (2014), etc.

The genus Phyllomya was erected by Robineau-Desvoidy in 1830 as a Holartic group and few species are found in place in the northern borders of oriental region. Eleven species have been described from various parts of the world (Villeneuve, 1937). From India, two species have been reported (Crosskey, 1976).

\section{Materials and Methods:}

For taxonomical studies, Tachinid flies have been collected from the fields of western Maharashtra at 15 days interval from June to February. The collected tachinid flies have been preserved in the laboratory by pinning and drying in the insect box. Taxonomical studies of Tachinids have been made on head, thorax, abdomen and their appendages. Measurements were taken with the help of ocular meter. The description of species was made with the help of appropriate literature (Crosskey, 1976; Wood, 1987; etc.).

\section{Results and Discussion:}

Male: $8.5 \mathrm{~mm}$ long, Head $0.76 \mathrm{~mm}$,Thorax $2.92 \mathrm{~mm}$, Abdomen $5.1 \mathrm{~mm}$, Wing $8.52 \mathrm{~mm}$ length and $2.84 \mathrm{~mm}$ width, Halter $1.53 \mathrm{~mm}$ length and $0.53 \mathrm{~mm}$ width.

HEAD- $0.76 \mathrm{~mm}$, Black in color; Vertex Narrow; Inner vertical bristles with single reclinate pair; Outer vertical bristle single pair, proclinate; Ocelli present; Ocellar bristles long; Frontal vita dark brown, narrow; Frontal bristles single row medioclinate; Face concave silvery white; Lower facial margin protruded forward; Vibrissa small weak; Facial ridge slightly concave; Parafacial Silvery white; Gena with small hairs, gena and parafacials appearing silvery but not reddish brown; Genal dilation weakly developed; Back of head Convex with few hairs; Eyes 0.42mm; Reddish brown in color; Dichoptic; Bare; Antenna silvery-light brown with scape short 0 . $7 \mathrm{~mm}$ in length, Pedicel short $0.09 \mathrm{~mm}$ with few hairs, First flagellomere $0.62 \mathrm{~mm}$, antennal third segment more than thrice as long as second segment; Arista plumose type; Proboscis well developed; Prementum short with labella; Palpus filiform- parallel sided, brownish.

THORAX- 2.92mm; Black with thin silvery pollinosity most evident on pleural regions; Humeral callus three setae dorsally projected; Proepisternum Bare; Proepimeron pair of setae present; Scutum 1.92; double dark bands; Acrostichal bristles strong, reclinate (Presutural 3+ Postsutural 3); Dorsal central bristles strong; reclinate (Presutural 3+ Postsutural 3); Notopleuron 2 setae; Postalar callus 2 setae; Scutellum 1mm; Basal scutellar bristles straight; Subapical scutellar bristles very long than other, strong; Subscutellum convex; Katepisternum with 2 strong setae; Anepimeron with single seta; Katepimeron bare; Anatergite bare; Anterior thoracic spiracle narrow,with closed fringes of hairs.

WING - 8.52mm, transparent with very faint brownish tinge to naked eye; Lower calypter small slightly separated from scutellum; Second 
costal section bare; Base of costa with costal bristle; costigeal setae strong conspicuously larger than basal scutellar setae; Fourth costal section longer than $6^{\text {th }}$ costal section; $\mathrm{R}_{1}$ bare; $\mathrm{Cu} \mathrm{A}_{1}$ bare; Bend of $\mathrm{M}$ distinct and shows small projection of $\mathrm{M}_{2}$; Wing cell $\mathrm{r}_{4+5}$ open; Cross vein $\mathrm{R}-\mathrm{M}$ present; Cross vein $\mathrm{d} \mathrm{M}-\mathrm{Cu}$ present; Anal vein not reaching towards hind margin of wing; Halter reddish yellow, $1.53 \mathrm{~mm}$ length, $0.53 \mathrm{~mm}$ width.

LEG -

Blackish brown; Fore and mid femora with row of spines ventrally; Fore tibia yellow, with 1 Preapical anterodorsal seta, fore tarsus brown; mid tibia yellow 1 preapical anteriodorsal setae present; Hind tibia yellow, 1 preapical posteroventral seta present, 1 antero dorsal bristles present; Hind coxa with 1 short setae.

\section{ABDOMEN-}

$5.1 \mathrm{~mm}$, black with white bands, not seen uniformly to naked eye elongated; Abdominal tergite $5^{\text {th }}$ as long as about $4^{\text {th }}$ tergite; Mid dorsal depression on syntergite $1+2$ not reaching of that segment; Tergite $5^{\text {th }}$ tapered at end; Discal bristles present Abdominal sternite overlapped by ventral edges of tergites; Spiracle remains on side of tergite 7

\section{GENITALIA-}

Terminalia retracted within abdominal tergite 5; Tergite 6 less reduced joining segment 7 .

COLOUR-

Black: Head, Thorax Abdomen

Brown: Antenna, Palpus,

Dark brown: Frontal vita,

Yellow: Fore Tibia, Mid Tibia,

Hind Tibia

Silvery white: Face, Parafacial, Reddish brown: Eyes,

HOST- Unknown

HOST PLANT- Caltropis sp. HOLOTYPE-

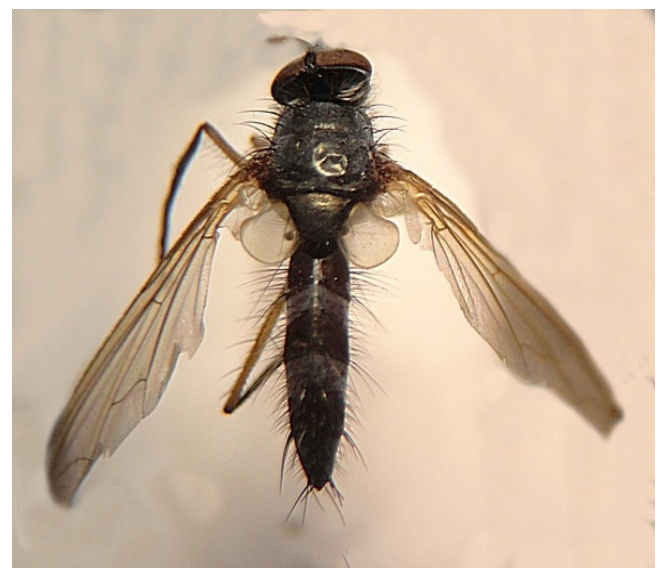

Figure. 1- Dorsal view
Male, India, Maharashtra, Coll. 8-VIII-2013, Panhala, P.M.Bhoje; antenna, wings, legs, tergite on slides, labeled as above.

PARATYPE- 3 Males, Sex ratio (M: F) 3:0, JuneFebruary same data as above.

\section{ETYMOLOGY-}

The species name is described from the Panhala region of Kolhapur where the type material has been collected.

\section{DISTRIBUTIONAL RECORD -}

India, Maharashtra, ô 1 Kolhapur 28- XI-2013; ô 1 Panhala 13-VIII- 2013; đ̂1 Amba 08-XI2013.

\section{REMARKS-}

According to key of Crosskey, 1976, this species runs close to Phyllomya gibsonomyides by having following characters,

1. Genal dilation weakly developed

2. Ocellar bristles long

3. Palpus filiform- parallel sided, brownish

4. Thorax black with thin silvery pollinosity most evident on pleural regions

5. Wings transparent with very faint brownish tinge to naked eye

However, it differs from the above species by following distinct characters,

1. Gena and parafacials appearing silvery but not reddish brown

2. Antenna silvery-light brown and antennal third segment more than thrice as long as second segment

3. Vibrissae weak not differentiated from hairs on vibrissal angle

4. Bend of $\mathrm{M}$ distinct and shows small projection of $\mathrm{M}_{2}$ on wing

5. Abdomen black with white bands, not seen uniformly to naked eye elongated

6. Legs brownish black with yellow tibia.

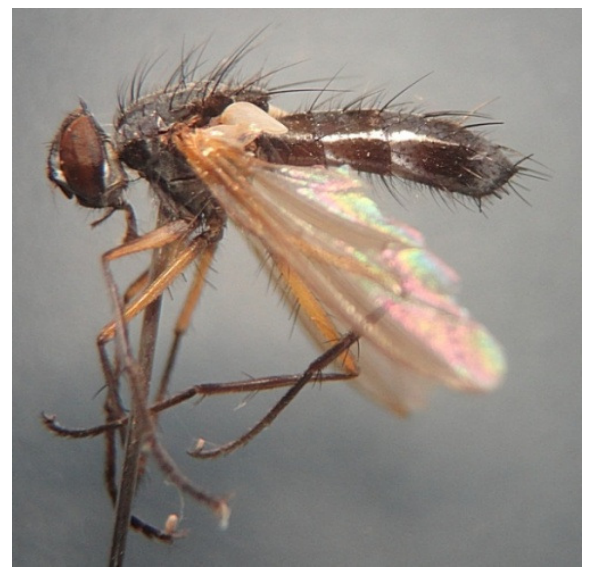

Figure. 2- Lateral view 


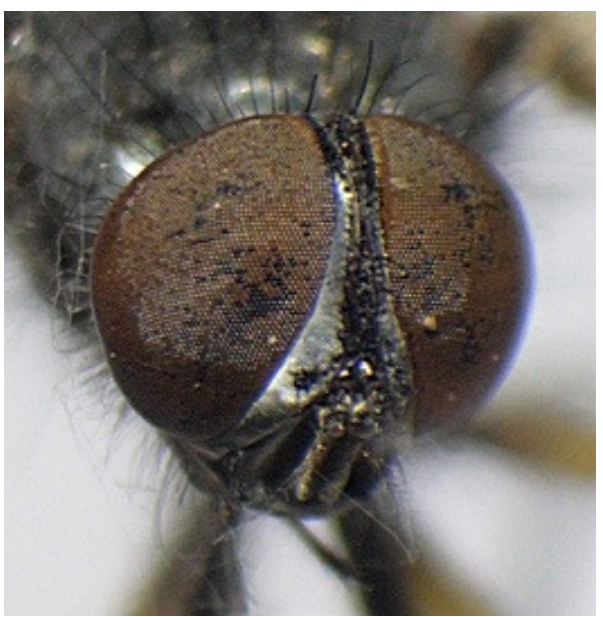

Figure. 3- Head front view

\section{Acknowledgement}

Authors are thankful to Shivaji University Kolhapur for providing facilities.

\section{References}

Crosskey, R. W. 1976. A taxonomic conspectus o $f$ the Tachinidae (Diptera) of the Oriental Region, Bulletin of The British Museum (Natural History). Entomology Supplement, 26, London. 357pp.

Irwin, M.E., Schlinger, E.I. and Thompson, F.C. 2003. Diptera, true flies. Pp. 692-702. In: Goodman, S.M. and Benstead, J.P., The Natural History of Madagascar. University of Chicago Press, Chicago and London. 1728 pp.

Lahiri, A.R. 2003. Diptera: Tachinidae, In: Fauna of Sikkim, State Fauna series 9 (Part-3): 387-399. Zoological Survey of India, Kolkata

Lahiri, A.R. 2006. Diptera: Tachinidae, In: Fauna of Nagaland, State Fauna series 12:199211.Zoological Survey of India, Kolkata

O'Hara JE. 2005. World genera of the Tachinidae (Diptera) and their regional occurrence.

http://www.nadsdiptera.org/Tach/Genera/gene rahom.

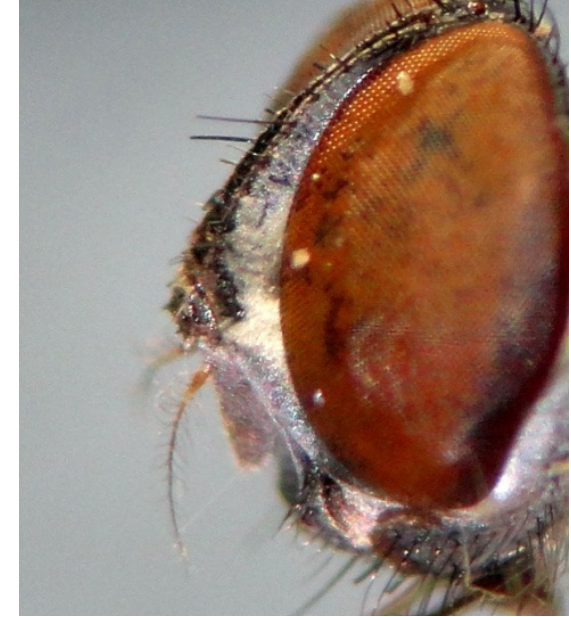

Figure. 4- Antenna lateral view

Stireman JO, O'Hara JE, Wood DM. 2006. Tachinidae: evolution, behavior, and ecology. Annual Review of Entomology 51: 525-555.

Tschorsnig H.-P. and Herting, B. 1994. Die Raupenfliegen (Diptera:Tachinidae) Mitteleuropas: Bestimmungstabellen und Angaben zur Verbreitung und Ökologie der einzelnen Arten. StuttgarterBeiträge zur Naturkunde (A) 506: 1-170.

Online authorized version of English translation by Rayner R. \& Raper C.: Tschorsnig H.-P. \& Herting B. 2001: The Tachinids (Diptera: Tachinidae) of Central Europe: Identification Keys for the Species and Data on Distribution and Ecology,

http://tachinidae.org.uk/site/downloads.php.

T .V. Sathe, P. M. Bhoje and A. S. Desai 2014. Floral host plants for Tachinid flies (Diptera: Tachinidae) from Kolhapur and Satara districts, India. Journal of entomological science. 38 (3), 183-188.

Villeneuve, J. 1937 Notes dipterologiques de chine. Bull. Annls Soc. ent.Bel. 77: 408-408.

Wood, D.M. 1987. Tachinidae. In: J.F McAlpine et al.: Manual of Nearctic Diptera 2(110): 11931269. 